\title{
Multiple-Stage Mineralization in the Huayangchuan U-REE- Mo-Cu-Fe Ore Belt of the Qinling Orogen, Central China: Geological and Re-Os Geochronological Constraints
}

\author{
Hongjun Jiang $\mathbb{1}^{1,3,6}$, Chunsi Yang ${ }^{1,3}$, Dequan Wang ${ }^{7}$, Hui Zheng ${ }^{1,3}$, Jie $\mathbf{L i}^{5}$, Huayong Chen $\mathbb{D}^{* 1,2,3,4}$ \\ 1. Key Laboratory of Mineralogy and Metallogeny, Guangzhou Institute of Geochemistry, Chinese Academy of Sciences, \\ Guangzhou 510640, China \\ 2. CAS Center for Excellence in Deep Earth Science, Guangzhou 510640, China \\ 3. University of Chinese Academy of Sciences, Beijing 100049, China \\ 4. Guangdong Provincial Key Laboratory of Mineral Physics and Materials, Guangzhou 510640, China \\ 5. State Key Laboratory of Isotope Geochemistry, Guangzhou Institute of Geochemistry, Chinese Academy of Sciences, \\ Guangzhou 510640, China \\ 6. Geological Party No. 214, Sino Shaanxi Nuclear Industry Group, Xi' an 710100, China \\ 7. Sino Shaanxi Nuclear Industry Group, Xi' an 710100, China
}

(D)Hongjun Jiang: https://orcid.org/0000-0002-5912-9330; (1)Huayong Chen: https://orcid.org/0000-0001-9106-9297

\begin{abstract}
The Huayangchuan ore belt is located in the western segment of Xiaoqinling Orogen in the southern margin of the North China Craton (NCC), and hosts voluminous magmatism and significant U-REE-Mo-Cu-Fe polymetallic mineralization. However, geochronological framework of the various mineralization phases in this region is poorly understood. Here, we present new Re-Os isochron ages on magnetite from the Caotan Fe deposit (2 $675 \pm 410 \mathrm{Ma}$, MSWD = 0.55), and on pyrite from the Jialu REE deposit $(2127 \pm 280 \mathrm{Ma}$, MSWD $=1.9)$ and Yuejiawa Cu deposit $(418 \pm 23 \mathrm{Ma}$, MSWD $=$ 11.5), and Re-Os weighted average model age on pyrite from the Taoyuan Mo-U deposit (235 $\pm 14 \mathrm{Ma}$, MSWD $=0.17$ ). These ages, combined with regional geology and mineralization ages from other deposits, suggest that mineralization in the Huayangchuan ore belt lasted from the Neoarchean to the Late Mesozoic. The mineralization corresponds to regional tectono-magmatic events, including the Neoarchean alkali magmatism (REE mineralization), Paleoproterozoic plagioclase-amphibolite emplacement (Fe mineralization), Paleoproterozoic pegmatite magmatism (U mineralization), Paleozoic Shangdan oceanic slab subduction-related arc magmatism ( $\mathrm{Cu}$ mineralization), Early Mesozoic Paleo-Tethys Ocean subduction-related arc magmatism (Mo-U mineralization), and Late Mesozoic Paleo-Pacific oceanic plate subduction direction change-related $\mathrm{Mo}(-\mathrm{Pb})$ mineralization. We proposed that the Huayangchuan ore belt has undergone prolonged metallogenic evolution, and the magmatism and associated mineralization were controlled by regional geodynamic events.

KEY WORDS: Re-Os dating, U-REE-Mo-Cu-Fe mineralization, Huayangchuan ore belt, extra-long metallogenic history, Qinling Orogen, geochemistry.
\end{abstract}

\section{INTRODUCTION}

Accurate determination of mineralization timing is a critical aspect in ore deposit research (Tan et al., 2006). Rhenium and osmium are siderophile and thiophile elements and show contrasting geochemical behavior in magmatism (Zhang and Gao, 2012). They are mainly enriched in many sulfides (e.g., molybdenite, pyrite, chalcopyrite, arsenopyrite, pyrrhotite) and magnetite, and are resistant to post-magmatic hydrothermal or

*Corresponding author: huayongchen@gig.ac.cn

(C) The Authors 2022. This article is published with open access at Springerlink.com

Manuscript received June 3, 2021.

Manuscript accepted September 28, 2021. metamorphic disturbance. This allows the Re-Os isotopic systematics to be reliable in dating metallic minerals and trace the metal origin (Wang et al., 2019; Zeng, et al., 2019; Huang et al., 2014; Jiang et al., 2000 and references therein).

The Huayangchuan ore belt has undergone multi-stage magmatism (Yang et al., 2019; Xue et al., 2018; Ding et al., 2016, 2011; Zhang et al., 2015; Hu et al., 2012; Qi et al., 2012; Jiao et al., 2010; Zhao et al., 2010; Zhu et al., 2008) and hosts diverse commodities, including mainly $\mathrm{Mo}, \mathrm{Cu}, \mathrm{Fe}, \mathrm{U}$ and REEs (Gao et al., 2019; He et al., 2016; Yuan et al., 2014; Stein et al., 1997; Huang et al., 1995). However, apart from the Huayangchuan U-polymetallic, Huanglongpu carbonatite-related Mo, and Jinduicheng porphyry Mo deposits, other REE, Fe and $\mathrm{Cu}$ mineralization occurrences in this belt are poorly documented, such as the Caotan $\mathrm{Fe}$, Yuejiawa $\mathrm{Cu}$, Taoyuan Mo-U,

Jiang, H. J., Yang, C. S., Wang, D. Q., et al., 2022. Multiple-Stage Mineralization in the Huayangchuan U-REE-Mo-Cu-Fe Ore Belt of the Qinling Orogen, Central China: Geological and Re-Os Geochronological Constraints. Journal of Earth Science, 33(1): 193204. https://doi.org/10.1007/s12583-021-1557-1. http://en.earth-science.net 
and Jialu REE deposits. Previous studies proposed that the mineralization mainly occurred in the Mesozoic, which is doubtful considering the multiphase magmatism and complex geological evolution of this region.

In this contribution, we summarize the geological information of various deposits in the Huayangchuan ore belt, most of which being firstly documented in this study, and present new Re-Os isotopic ages of pyrite and magnetite in these deposits. Integrating our new geochronological results and published ones from well-known deposits in this belt, we demonstrate that mineralization in this area comprises at least six phases and discuss the relationship between mineralization and regional tectonic evolution.

\section{GEOLOGICAL SETTING}

\subsection{Regional Geology}

The Qinling Orogen, bounded by the Sanmenxia-Baofeng fault to the north and the Longmenshan-Dabashan fault to the south, has experienced a prolonged continental divergence and convergence between the North China Craton (NCC) and the Yangtze Craton (YZC) (Fig. 1a; Xue et al., 2020; Bao et al.,
2014). From north to south, the orogen can be divided into the southern margin of NCC, North Qinling belt, South Qinling belt, and the northern margin of YZC by the Luonan-Luanchuan fault, and Shangdan and Mianlue sutures, respectively (Fig. 1b; Dong et al., 2011; Zhang et al., 1995).

The Huayangchuan U-REE-Mo-Cu-Fe ore belt is located in the southern margin of the NCC, which consists mainly of the Archean-Paleoproterozoic basement of the Taihua Group and Proterozoic volcanic-sedimentary cover of the Xiong' er, Guandaokou and Luanchuan groups (Zhang et al., 1995). The Taihua Group is traditionally separated into upper and lower units by the $2.3 \mathrm{Ga}$ boundary: The lower unit is mainly composed of amphibolites, gneisses and minor granulites, whilst the upper unit consists of garnet-sillimanite gneisses, graphite gneisses, marbles, quartzites, banded iron formations (BIFs), and minor mafic granulites and amphibolites (Cai et al., 2020). The Paleo-Mesoproterozoic Xiong' er Group comprises mainly mafic to felsic volcanic rocks with minor sedimentary and pyroclastic rocks, with zircon $\mathrm{U}-\mathrm{Pb}$ ages of $1.78-1.45 \mathrm{Ga}$ (Cai et al., 2020). The Mesoproterozoic Guandaokou Group consists of low-grade metamorphosed terrigenous clastic rocks and marine
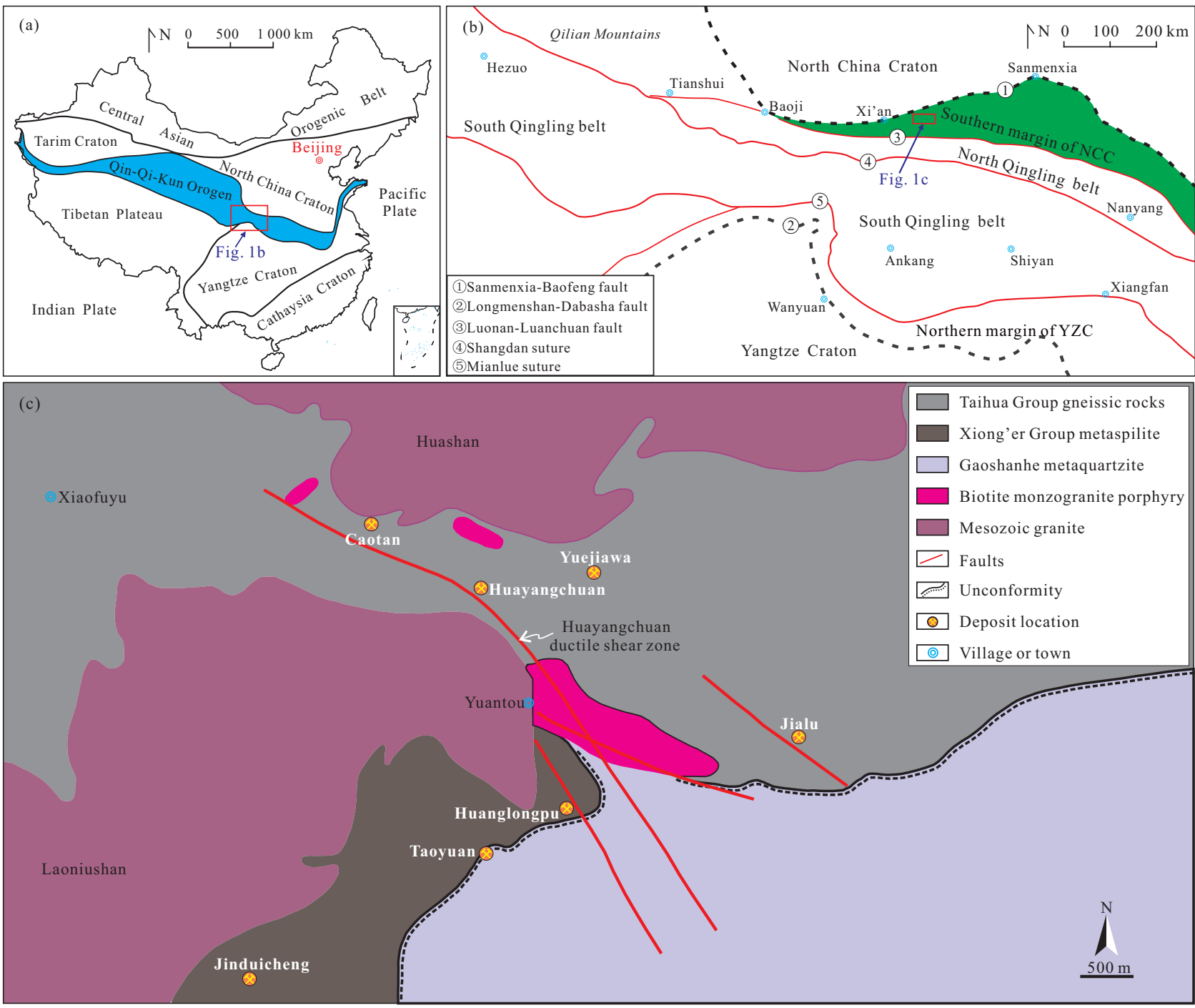

Figure 1. (a) Tectonic map of China showing the location of the Qinling Orogen (after Chen et al., 2010); (b) tectonic subdivision of the Qinling Orogen (after Yang et al., 2019); (c) simplified geological map of the Huayangchuan ore belt (after Huang et al., 1984). 
carbonates. The Neoproterozoic Luanchuan Group comprises siliceous/carbonaceous slates, quartzites and marbles (Cao et al., 2017). Intrusive rocks are widespread in the southern NCC margin, including the Archean gneissic tonalite-trondhjemitegranodiorite (TTG) suite (e.g., Taiyuling and Wengchapu; Zheng et al., 2020a, b), Paleoproterozoic-Mesoproterozoic granites (Yuantou and Huayangchuan A-type granites, Xiaohe gneissic granite; Deng et al., 2019; Xue et al., 2018; Li, 2011) and mafic dyke swarms (Bi et al., 2011; Wang et al., 2008), Mesozoic carbonatite dykes (Huangyanchuan and Huanglongpu; Zheng et al., 2020a, b), and granitoid batholiths (Huashan and Laoniushan; Yang et al., 2019; Hu et al., 2012). Major regional structures in the southern NCC margin include a series of nearly EW-trending faults, superimposed by NE-trending secondary faults and fractures (Zheng et al., 2020a, b), which control the distribution of some deposits. Apart from dozens of medium to large $\mathrm{Au}$ deposits in the northeastern part of the southern NCC margin, there are also various other types of deposits in the southwestern part of the margin, including porphyry Mo (Jinduicheng and Shijiawan), carbonatite-related Mo (Huanglongpu), U-polymetallic (Huayangchuan), Mo-U (Taoyuan), Fe (Caotan), Cu (Yuejiawa), and REE (Jialu) ones.

\subsection{Geology of Representative Deposits in the Huayang- chuan Ore Belt \\ 1.2.1 Jialu REE deposit}

The Jialu deposit is located in the eastern part of the Huayangchuan ore belt (Fig. 1c). The deposit was first discovered in the early 1970s, and contains a reserve of $401.84 \mathrm{t}$ $\left(\mathrm{Y}_{2} \mathrm{O}_{3}+\mathrm{Yb}_{2} \mathrm{O}_{3}\right) @ 0.06 \%$ (Huang et al., 1972, unpubl. report).
Stratigraphic units at Jialu comprise mainly the NeoarcheanProterozoic high-grade metamorphic Taihua Group and Quaternary sediments. The Taihua Group contains mainly (hornblendebiotite) plagiogneiss. These metamorphic rocks are characterized by obvious fold deformation. Intrusive rocks at Jialu contain mainly granite stocks and dykes of granitic pegmatite, syenite porphyry, diabase and lamprophyre. Three major sets of faults (NE-, NW- and ENE-trending) have been identified. The orebodies are distributed along the NE-/ENE-trending faults, and are often crosscut by the NW-trending faults (Fig. 2a; Huang et al., 1972, unpubl. report).

Based on the orebody occurrence and spatial distribution, the Jialu REE deposit can be divided into the western and eastern ore section, with the former being more important (Fig. 2a). The orebodies were strictly controlled by the distribution of quartz-calcite veins (probably carbonatite dykes), which contain minor coarse-grained pyrite (Fig. 3a). The pyrite is euhedral cubic and distributes among the calcite with straight boundary (Fig. 3b), indicating that they were formed simultaneously. Hydrothermal alterations around the orebodies include K-feldspar-albite and quartz-barite alterations (Fig. 3c). Ore minerals include mainly bastnaesite, parasite, xenotime, and monazite (Huang et al., 1972, unpubl. report).

\subsubsection{Caotan Fe deposit}

The Caotan Fe deposit is located south of the GangouWengyuling syncline, $1 \mathrm{~km}$ northwest of the Huayangchuan deposit (Fig. 1c). The deposit contains a reserve of 65208 t Fe @ $42 \%$. Exposed strata at Caotan include mainly the Taihua Group (upper unit) and Quaternary sediments (Fig. 2b; Bai et

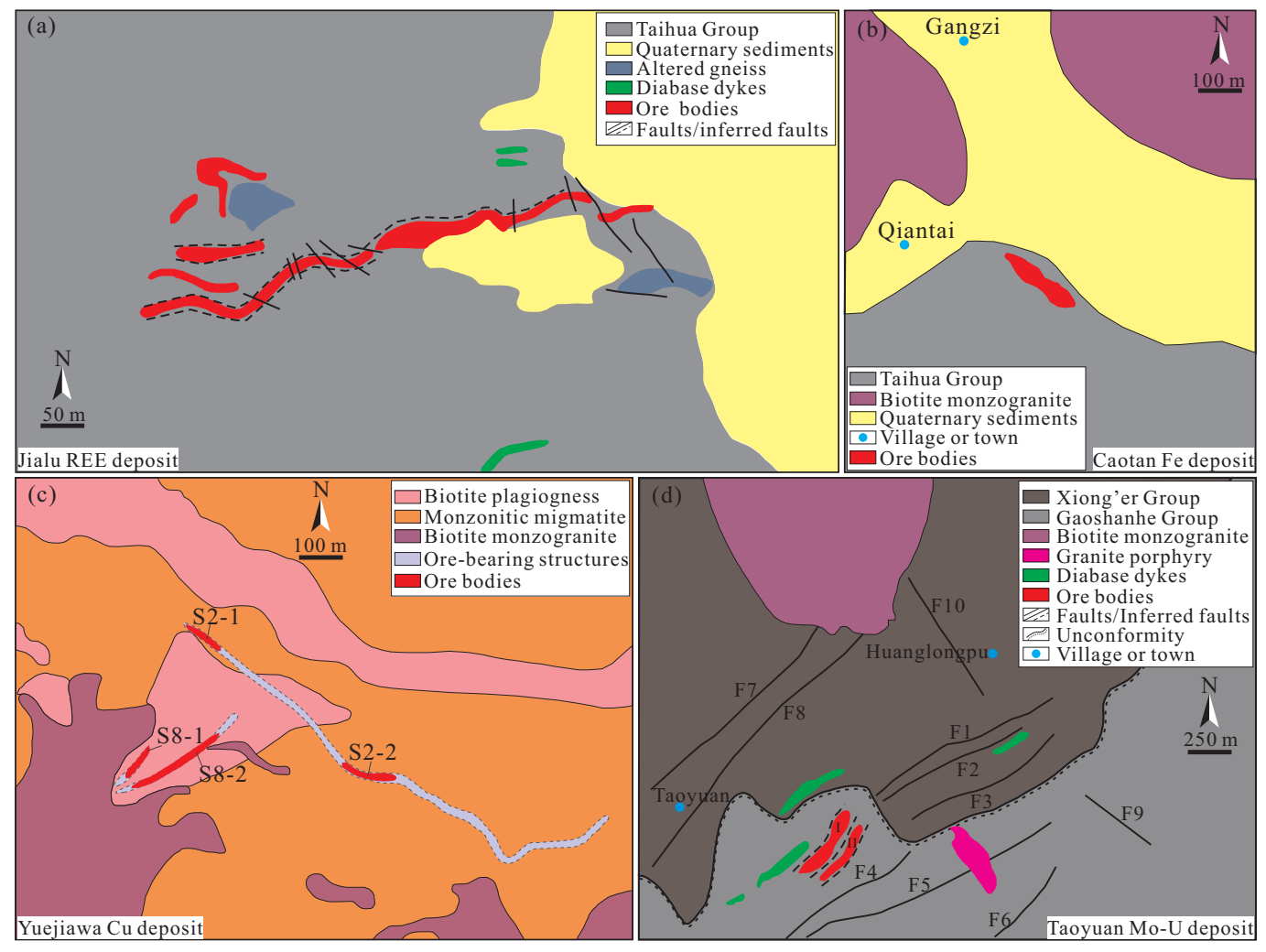

Figure 2. Simplified geological map of (a) Jialu REE deposit (after Huang et al., 1972, unpubl. report); (b) Caotan Fe deposit (after Bai et al., 2002, unpubl. report); (c) Yuejiawa Cu deposit (after Liu, 2002, unpubl. report); (d) Taoyuan Mo-U deposit (after Peng et al., 1983, unpubl. report). 

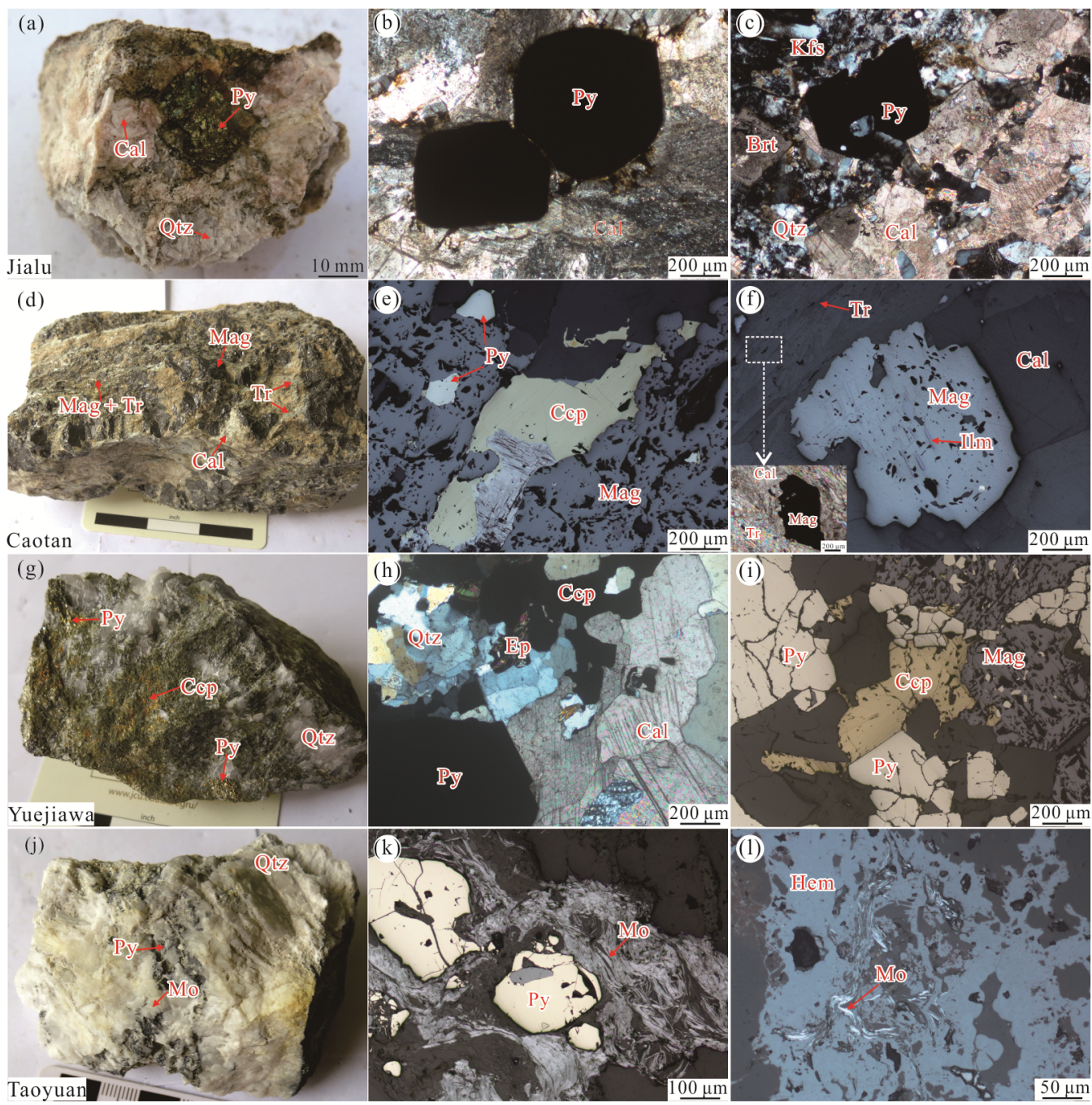

Figure 3. Representative photographs and photomicrographs of mineral assemblages of Jialu REE deposit (a)-(c); Caotan Fe deposit (d)-(f); Yuejiawa Cu deposit (g)-(i); and Taoyuan Mo-U deposit (j)-(1). Mag. Magnetite; Ilm. ilmenite; Hem. hematite; Py. pyrite; Ccp. chalcopyrite; Mo. molybdenite; Kfs. K-feldspar; Qtz. quartz; Cal. calcite; Brt. barite; Tr. tremolite; Ep. epidote.

al., 2002, unpubl. report). The Taihua Group (upper unit) contains medium-high-grade gneiss, consisting of hornblende plagiogneiss with minor biotite plagiogneiss interlayer and migmatite. The Jurassic-Cretaceous Huashan granitic intrusions (233-132 Ma) occurred in the northern part of the Caotan deposit (Yang et al., 2019; Hu et al., 2012; Guo et al., 2009 and reference therein).

The Caotan Fe deposit is hosted in the Taihua Group (upper part) hornblende plagiogneiss, and the orebodies are often lenticular-shaped (Fig. 2b). The ores are mainly massive, crumby, disseminated, or lamellar. Major metallic minerals include magnetite with accessory chalcopyrite and pyrite, whilst non-metallic minerals include mainly calcite, tremolite, muscovite, chlorite (Figs. 3d, 3e), and minor phlogopite. Calcite + pyrite + chalcopyrite veins crosscut the magnetite (Fig. 3e) and ilmenite crystalized from magnetite (Fig. 3f).

\subsubsection{Yuejiawa $\mathrm{Cu}$ deposit}

The Yuejiawa $\mathrm{Cu}$ deposit is located $1 \mathrm{~km}$ northeast of the Huayangchuan deposit and north of the Huayangchuan ductile shear zone, which is composed of tectonic schist and augen gneiss (Fig. 1c; Guo et al., 2008). The deposit contains a metal reserve of 8642 t Cu@1.49\%. Exposed stratigraphy at Yuejiawa comprises the Taihua Group biotite \pm hornblende plagiogneiss, and biotite-monzonitic migmatite (Fig. 2c; Liu, 2002, unpubl. report). The Paleoproterozoic Huayangchuan and Yuantou granites $(\sim 1.8 \mathrm{Ga})$ were reported locally (Deng et al., 2019; Yang et al., 2019; Xue et al., 2018).

Mineralization at Yuejiawa occurred mainly in quartzsulfide veins and minor in granitic veinlets and cataclastic gneiss, which is strictly controlled by the NW-/NE-trending faults (Fig. 2c). A total of eight orebodies have been identified. Extensive hydrothermal alterations around the orebodies include quartz, calcite, pyrite, epidote, sericite, and chlorite (Fig. $3 \mathrm{~g}$ ), with the former three being mineralization-related (Fig. $3 \mathrm{~h}$ ). The ores are mainly massive, vein, disseminated or (locally) brecciated. Ore minerals comprise dominantly chalcopyrite (Fig. 3i) and minor bornite, with textures being anhedralsubhedral and poikilitic (Liu, 2002, unpubl. report). Euhedralsubhedral pyrite shows straight boundary with chalcopyrite (Fig. 3i), indicating that they were co-precipitated. 


\subsubsection{Taoyuan Mo-U deposit}

The Taoyuan Mo-U deposit is located $3 \mathrm{~km}$ southwest of the Huanglongpu Mo deposit (Fig. 1c), and contains a reserve of 24347.4 t Mo@0.08\% (U resource data are confidential). Stratigraphic units at Taoyuan comprise the Proterozoic Xiong'er and Gaoshanhe groups (Fig. 2d; Peng et al., 1983; unpubl. report). The Xiong'er Group is composed of (basaltic-) andesite, andesite porphyrite, tuff and phyllitic tuffaceous slate. The Gaoshanhe Group consists of tuffaceous slate and metaquartz sandstone. Medium-grained biotite monzogranite, granite porphyry and minor diabase dykes locally intruded the Xiong'er and Gaoshanhe groups.

Major structures at Taoyuan include a series of NEtrending and two NW-trending faults (Fig. 2d). Two lenticular Mo-U orebodies have been found in the Gaoshanhe Group, which are strictly controlled by the NE-trending faults. Mineralization is often developed in quartz-sulfide veins (Fig. 3j). Hydrothermal alterations at Taoyuan include K-feldspar, hematite, pyrite, biotite, sericite, limonite and silicification (Figs. 3k, 31). Metallic minerals include mainly molybdenite, pyrite, chalcopyrite, galena, pitchblende, coffinite, and uranium blacks (Peng et al., 1983; unpubl. report), with the molybdenite commonly coexisting with pyrite (Fig. 3k). The ores occur mainly as veinlet and stockwork, and locally breccia.

\section{SAMPLING AND ANALYTICAL METHODS}

Based on detailed field geological investigation and macro/ microscopic textural observations, four pyrite samples from Jialu, four pyrite samples from Yuejiawa, and four magnetite samples from Caotan of the main ore stage were collected to constrain the formation ages of these deposits. For the Taoyuan deposit, due to strong weathering of the surface samples, the purity of separated molybdenite is not sufficient for Re-Os dating, thus only two pyrite samples were Re-Os dated. The pyrite and magnetite grains were separated by heavy liquid and magnetic techniques, respectively. They were then purified by hand-picking under a binocular microscope and examined using X-ray to ensure $99 \%$ purity. Before the analysis, the pyrite and magnetite samples were crushed and powdered to 40-60 mesh using an agate mortar.

Pyrite and magnetite Re-Os dating was carried out at the State Key Laboratory of Continental Dynamics, Northwest University (NWU). Approximately $0.5-2.0 \mathrm{~g}$ of the pyrite and magnetite powder were weighed and placed into Carius tubes. Appropriate amounts of the individual ${ }^{185} \mathrm{Re}$ and ${ }^{190} \mathrm{Os}$ spike solutions, $2.5 \mathrm{~mL}$ concentrated $\mathrm{HCl}$ and $7.5 \mathrm{~mL}$ concentrated $\mathrm{HNO}_{3}$ were accurately measured and carefully added. Then, the bottom parts of the Carius tubes were chilled in a bath containing a freezing liquid nitrogen and ethanol mixture. When the liquid in the Carius tubes was frozen completely, the top of Carius tubes were carefully sealed using a natural gas torch, and then placed in a stainless-steel jacket and heated in an oven at $230^{\circ} \mathrm{C}$ for $24 \mathrm{~h}$. After dissolution, the Carius tubes were again chilled in the liquid nitrogen-ethanol bath before opening. After thawing, the contents were poured into $50 \mathrm{~mL}$ centrifuge tubes to allow precipitation of the residual solids. The supernatant solutions were transferred into $33 \mathrm{~mL}$ PFA vials and subjected to Os solvent extraction by $\mathrm{CCl}_{4}$, followed by back- extraction into concentrated $\mathrm{HBr}$ at room temperature. The extracted Os fraction was further purified by micro-distillation and loaded onto $99.999 \%$ Pt filaments, then $\mathrm{Ba}(\mathrm{OH})_{2}$ emitter solution was loaded on top of the sample to enhance the ion emission (Birck et al., 1997). After the Os extraction, the remaining Re-bearing solutions were evaporated to dryness, and the residues were dissolved in $1 \mathrm{~mL} \mathrm{HCl}(6 \mathrm{~mol} / \mathrm{L})$. The solutions were again evaporated to dryness, and the residues were re-dissolved in $10 \mathrm{~mL} \mathrm{HCl}(1 \mathrm{~mol} / \mathrm{L})$ on a hot plate at $80^{\circ} \mathrm{C}$ for 50 minutes. Bio-Rad Poly-Prep columns filled with $2.0 \mathrm{~mL}$ pre-cleaned anion exchange resin were used for the Re separation and purification (Morgan and Walker, 1989). Isotopic compositions of the purified Re factions were measured using ICPMS. The Os isotopes were measured with a Thermo Finnigan Triton thermal ionization mass spectrometer in negative ionization mode (N-TIMS). Detailed analytical procedures are as those described in Li et al. (2014). Uncertainties were determined by the uncertainties of the blank at the $2 \sigma$ level. The ${ }^{187} \mathrm{Re}$ decay constant of $1.666 \times 10^{-11} \mathrm{a}^{-1}$ (Smoliar et al., 1996) and Re-Os isochron ages were calculated using Isoplot ver. 3.0 (Ludwig, 2003).

\section{RESULTS}

The total Re and Os concentrations in the Jialu pyrite are of $27.70 \mathrm{ppt}-90.40 \mathrm{ppt}$ and $4.15 \mathrm{ppt}-82.80 \mathrm{ppt}$, respectively, with ${ }^{187} \mathrm{Re} /{ }^{188} \mathrm{Os}=5.31-64.90$ and ${ }^{187} \mathrm{Os} /{ }^{188} \mathrm{Os}=0.20-2.90(\mathrm{Ta}-$ ble 1). The low ratios of ${ }^{187} \mathrm{Re} /{ }^{188} \mathrm{Os}(<5000)$ and ${ }^{187} \mathrm{Os} /{ }^{188} \mathrm{Os}$ $(<50)$ indicate that these samples are typical magmatic sulfides and the traditional ${ }^{187} \mathrm{Re} /{ }^{188} \mathrm{Os}$ versus ${ }^{187} \mathrm{Os} /{ }^{188} \mathrm{Os}$ isochron ages are appropriate for them (Stein et al., 2000). Four pyrite samples yielded a well-defined ${ }^{187} \mathrm{Re} /{ }^{188} \mathrm{Os}$ versus ${ }^{187} \mathrm{Os} /{ }^{188} \mathrm{Os}$ isochron age of $2675 \pm 410 \mathrm{Ma}\left(\mathrm{MSWD}=0.55\right.$; initial ${ }^{187} \mathrm{Os} /{ }^{188} \mathrm{Os}$ ratio $=-0.041 \pm 0.040$; Fig. $4 \mathrm{a}$ ), and plot closely along the ReOs isochron, indicating that the dates are credible.

The Caotan magnetite samples have total Re and Os concentrations of $17.90 \mathrm{ppt}-26.70 \mathrm{ppt}$ and $0.82 \mathrm{ppt}-2.05 \mathrm{ppt}$, respectively, with ${ }^{187} \mathrm{Re} /{ }^{188} \mathrm{Os}=62.70-702.00$ and ${ }^{187} \mathrm{Os} /{ }^{188} \mathrm{Os}=$ $3.91-29.40$ (Table 1). They also have low ratios of ${ }^{187} \mathrm{Re} /{ }^{188} \mathrm{Os}$ and ${ }^{187} \mathrm{Os} /{ }^{188} \mathrm{Os}$, indicating that the magnetite samples are typical oxides and the traditional ${ }^{187} \mathrm{Re} /{ }^{188} \mathrm{Os}$ versus ${ }^{187} \mathrm{Os} /{ }^{188} \mathrm{Os}$ isochron ages are suitable for them (Stein et al., 2000). Four magnetite samples yielded a well-defined Re-Os isochron age of $2127 \pm 208 \mathrm{Ma}(\mathrm{MSWD}=1.9)$, with an initial ${ }^{187} \mathrm{Os} /{ }^{188} \mathrm{Os}$ ratio of $1.61 \pm 0.46$ (Fig. 4b). According to the isotope equation of Walker et al. (1994) and Selby et al. (2007), the calculated magnetite individual model ages range from 2929 to $2124 \mathrm{Ma}$ (Table 1), with a weighted average model age of $2105 \pm 380$ Ma. This is consistent with the isochron age of $2127 \pm 208$ Ma, suggesting that the ${ }^{187} \mathrm{Re} /{ }^{188} \mathrm{Os}$ versus ${ }^{187} \mathrm{Os} /{ }^{188} \mathrm{Os}$ isochron age is robust.

The Yuejiawa pyrite samples contain relatively high Re (1 $637.00 \mathrm{ppt}-8021.00 \mathrm{ppt}$ ) but low Os (5.83 ppt-27.90 ppt) contents, with ${ }^{187} \mathrm{Re}=1025.00 \mathrm{ppt}-5021.00 \mathrm{ppt}$ and ${ }^{187} \mathrm{Os}=$ $8.27 \mathrm{ppt}-36.50 \mathrm{ppt}$. These features are similar to the molybdenite samples, with over half of ${ }^{187} \mathrm{Os}$ in the total Os, indicating that the pyrite are low level highly radiogenic minerals (LLHR minerals; Stein et al., 2000). Thus, the traditional ${ }^{187}$ Re versus ${ }^{187} \mathrm{Os}$ isochron age is likely suitable. Four pyrite samples yield- 


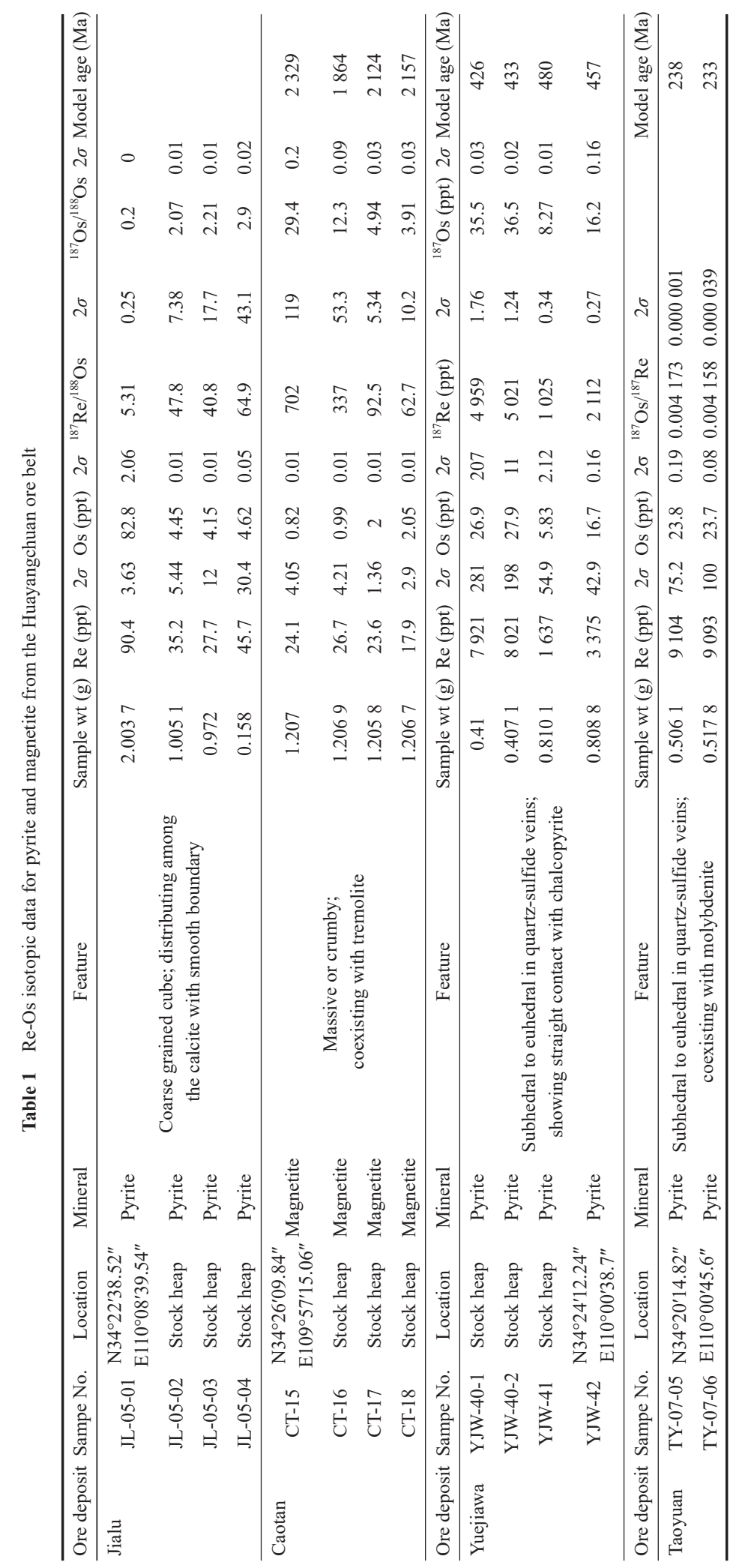



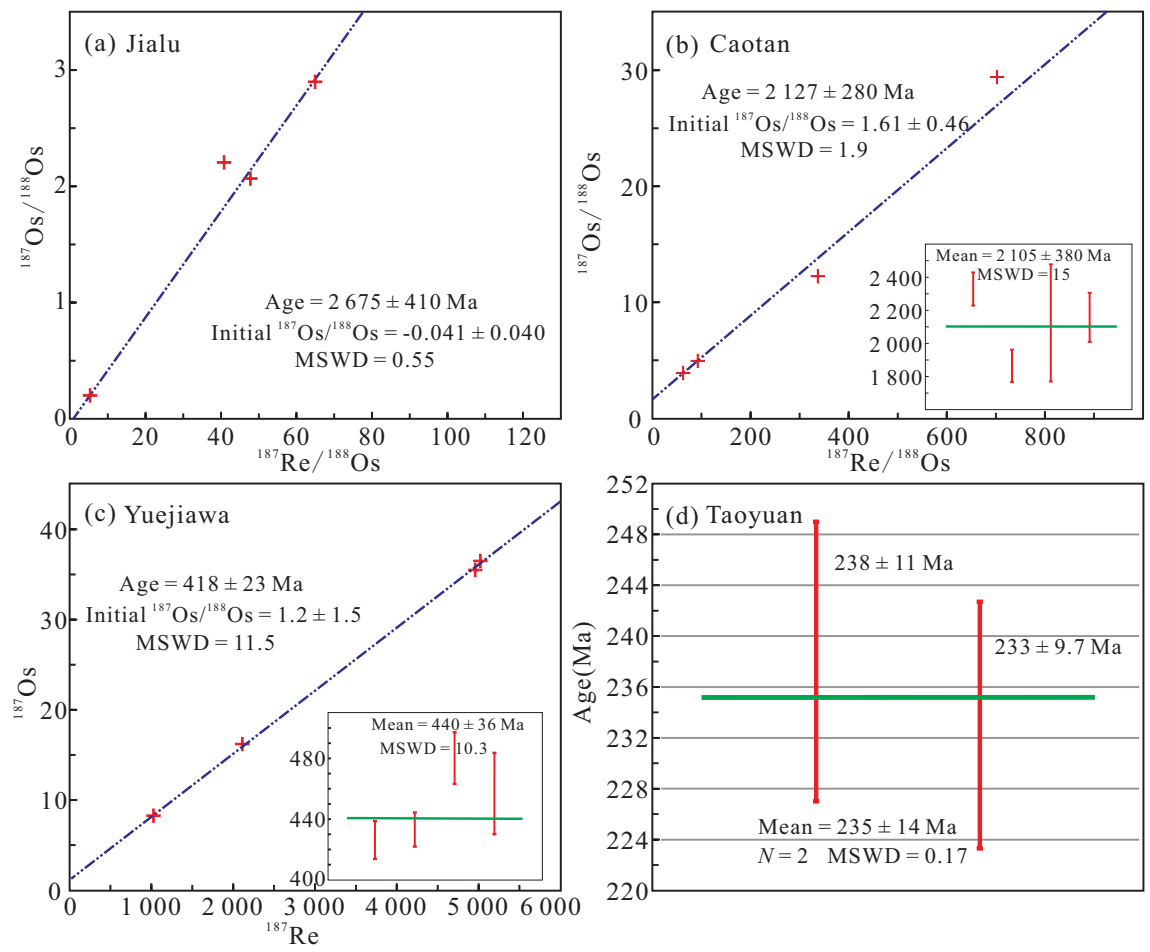

Figure 4. (a), (b) ${ }^{187} \mathrm{Re} /{ }^{188} \mathrm{Os}$ vs. ${ }^{187} \mathrm{Os} /{ }^{188} \mathrm{Os}$ plots for (a) pyrite from the Jialu REE deposit and (b) magnetite from the Caotan Fe deposit; (c) ${ }^{187} \mathrm{Re}$ vs. ${ }^{187} \mathrm{Os}$ plot for pyrite from the Yuejiawa $\mathrm{Cu}$ deposit; (d) weighted average model age diagram for pyrite from the Taoyuan Mo-U deposit.

ed a well-constrained ${ }^{187} \mathrm{Re}$ versus ${ }^{187} \mathrm{Os}$ isochron age of $418 \pm$ $23 \mathrm{Ma}\left(\mathrm{MSWD}=11.5\right.$; initial ${ }^{187} \mathrm{Os} /{ }^{188} \mathrm{Os}=1.2 \pm 1.5$; Fig. $\left.4 \mathrm{c}\right)$. Using the isotope equation of $t_{\text {model }}=\ln \left({ }^{187} \mathrm{Os} /{ }^{187} \mathrm{Re}+1\right) / \lambda$, where $\lambda=1.6668 \times 10^{-11}$ (Selby et al., 2007; Smoliar et al., 1996), the calculated individual pyrite model ages range from 480 to $426 \mathrm{Ma}$, with the weighted average model age of $440 \pm$ $36 \mathrm{Ma}$. The consistency between the weighted average model age and ${ }^{187} \mathrm{Re}$ versus ${ }^{187} \mathrm{Os}$ isochron age indicates that the latter is reliable.

The Taoyuan pyrite samples also have high Re (9 093.00 ppt-9 104.00 ppt) and low Os (23.70 ppt-23.80 ppt) concentrations, similar to the Yuejiawa pyrites and can be defined as the LLHR mineral. However, the ${ }^{187} \mathrm{Re}$ versus ${ }^{187} \mathrm{Os}$ isochron age is not available due to only two samples. Previous studies suggested that the Re-Os model age can be preferred for dating LLHR samples (Selby et al., 2009; Stein et al., 2000). Thus, we consider that the Re-Os model age can represent the timing of Taoyuan pyrite mineralization. The two pyrite samples have ${ }^{187} \mathrm{Os} /{ }^{187} \mathrm{Re}=0.004173$ and 0.004158 , with corresponding model age of 238 and $233 \mathrm{Ma}$, respectively, yielding a weighted average model age of $235 \pm 14$ Ma $($ MSWD $=0.17$; Fig. 4d).

\section{DISCUSSION}

\subsection{Archean REE Mineralization}

Previous studies suggested that the Jialu is a medium-high temperature quartz-carbonatite-type REE deposit (Huang et al., 1972; unpubl. report). Our observations show that the pyrite is intergrown with quartz and calcite (Figs. 3a, 3b), and thus the pyrite age can represent the quartz-carbonatite vein intrusion age. Considering that the REE mineralization commonly occurs in these veins, similar to many other carbonatite-hosted
REE deposits (e.g., the giant Bayan Obo REE deposit; Li et al., 2021), we infer that the Jialu REE mineralization occurred at ca. $2675 \mathrm{Ma}$.

This Neoarchean ore-forming age at Jialu is broadly coeval with the widespread TTG magmatism (ca. 2 802-2 506 Ma) in the Xiaoqinling District (Jia, 2016), which were mainly derived from the juvenile crust source and represent the MesoNeoarchean NCC crustal growth (Jia et al., 2020; Diwu et al., 2018). This implies that the tectonic events in ca. $2.8-2.5 \mathrm{Ga}$ may have formed both voluminous magmatic rocks and alkalimagmatism-related REE mineralization. Our new age data and published ones indicate that the Jialu REE deposit may represent the earliest mineralization event in the Xiaoqinling district, yet there is no other analogical quartz-carbonatite-type REE deposit reported, and the adjacent Huayangchuan and Huanglongpu carbonatites were dated to be ca. 220-200 Ma (Fig. 5; Zheng et al., 2020a, b; Song et al., 2016). Therefore, any genetic link between these carbonatite-related deposits in this region remains unclear.

\subsection{Proterozoic Fe and U Mineralization}

The Caotan Fe deposit is mainly composed of magnetite, calcite and some tremolite (Fig. 3d), which is distinct from typical BIFs. The distinction is also evidenced from the ilmenite precipitating from magnetite and calcite-sulfide veinlets crosscutting magnetite (Figs. 3e, 3f). These features are partially similar to skarn-type Fe deposit. Four Caotan magnetite samples yielded Re-Os isochron age of $2127 \pm 208 \mathrm{Ma}$ (MSWD = 1.9) and weighted average model age of $2105 \pm 380 \mathrm{Ma}$, implying that the mineralization occurred in the Paleoproterozoic.

Similar Paleoproterozoic ages were reported for the TTG rocks, dioritic gneiss, and the plagioclase-amphibolite in the 


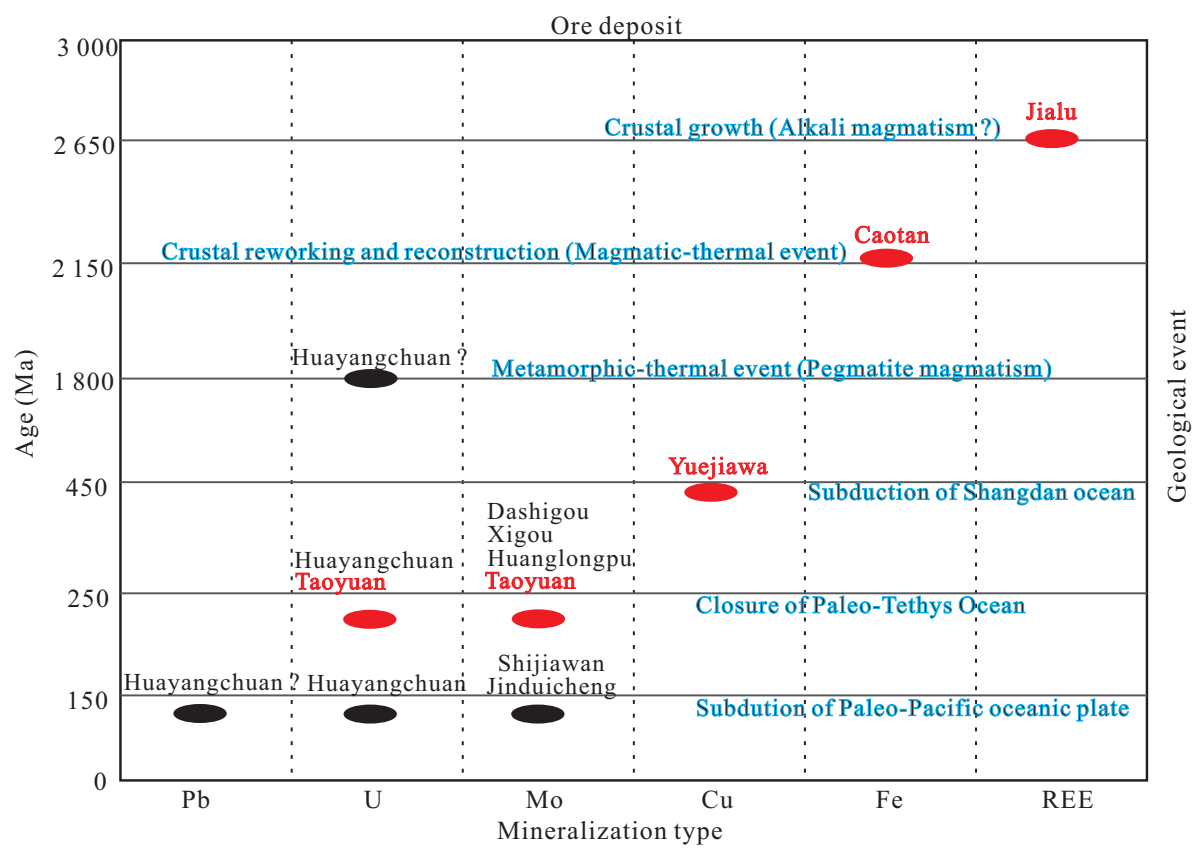

Figure 5. Age summary for major mineralization and geological events in the Huayangchuan ore belt.

Xiaoqinling District (ca. 2 360-2 240 Ma, peak 2310 Ma) (Diwu et al., 2018; Jia, 2016). Some younger zircons (ca. 2 192$2152 \mathrm{Ma}$ ) from the TTG rocks were interpreted to be late magmatic (Jia, 2016), and thus the Caotan Fe mineralization was likely caused by the 2.3-2.2 Ga magmatism (probably forming the protolith of plagioclase amphibolite), which was resulted from the crustal reworking and reconstruction in the Xiaoqinling District (Diwu et al., 2018; Jia, 2016). Given the 2.45$2.20 \mathrm{Ga}$ global magmatic quiescence (Condie and Aster, 2010; Condie et al., 2009), the coeval Caotan Fe mineralization and associated magmatism may have some important implications for the evolution of the Qinling Orogen.

Moreover, 1.9-1.8 Ga metamorphic zircons are common in the Taihua Complex (Diwu et al., 2018), coeval with the ca. 1.9-1.8 Ga regional metamorphic event in the NCC (Jia, 2016). This metamorphic event is also accompanied by some $1.8 \mathrm{Ga}$ pegmatite-hosted $\mathrm{U}$ deposits in the NCC, including the Lianshanguan, Wengquangou, Pinglu 405, and Hongshiquan (Jiang et al., 2020 and reference therein). This indicates that the $\sim 1.8 \mathrm{Ga}$ uranium mineralization occurred widely in the NCC, which is also supported by the discovery of the Huayangchuan K-feldspar pegmatite bearing U (-REE) mineralization in the Xiaoqinling District (Fig. 5; Jiang et al., 2020).

\subsection{Paleozoic Cu Mineralization}

The Yuejiawa $\mathrm{Cu}$ mineralization is fault-controlled and occurs mainly in quartz-sulfide veins, with coexisting pyrite and chalcopyrite (Fig. 3i). Thus, the Late Silurian-Early Devonian pyrite Re-Os isochron age $(418 \pm 23 \mathrm{Ma})$ can approximate the $\mathrm{Cu}$ mineralization age. However, no coeval magmatism was reported in the southern NCC margin. Considering the Shangdan oceanic slab may have subducted underneath the North Qinling belt in the Early Paleozoic, forming many arc-related gabbroic and granitic intrusions with ages of ca. 514-420 Ma (Dong and Santosh, 2016), we infer that the Yuejiawa $\mathrm{Cu}$ mineralization (in the southern NCC margin) was formed by far-field effect of the Shangdan Ocean closure. This is supported by the neighboring Huayangchuan ductile shear zone (active at ca. 419-417 $\mathrm{Ma})$, which was interpreted to be resulted from the tectonic deformation of Caledonian North Qinling orogeny (Guo et al., 2008). The adjacent location and highly similar age between the Yuejiawa $\mathrm{Cu}$ mineralization and the Huayangchuan ductile shear zone suggest that they may have been genetically related to the Early Devonian North Qinling orogeny.

\subsection{Mesozoic Mo, $\mathrm{U}$ and Pb Mineralization}

The Taoyuan Mo-U deposit is hosted by the Gaoshanhe Group meta-quartz sandstone and controlled by NE-trending faults. The molybdenite and pyrite are often intergrown, indicating that they are coeval (Fig. 3k). Thus, the calculated pyrite weighted average model age of ca. $235 \pm 14$ Ma can represent the timing of Mo-U mineralization. This age is broadly similar to the mineralization ages of the Huayangchuan U-polymetallic (209-181 Ma; Zheng et al., 2020a; Qiu et al., 1993; Yu, 1992), Huanglongpu Mo (231-206 Ma; Song et al., 2016; Stein et al., 1997; Huang et al., 1995, 1984), and Xigou Mo (212.4 Ma; Yuan et al., 2014) deposits. Moreover, the Wenyu hornblende monzogranite (205 $\pm 2 \mathrm{Ma})$ and Huayangchuan granodiorite $(233.3 \pm 1.4 \mathrm{Ma})$ in the Huashan pluton (Yang et al., 2019; Hu et al., 2012), and the adamellite (223 $\pm 1 \mathrm{Ma})$, granodiorite $(222 \pm 1 \mathrm{Ma})$, and coarse-grained biotite monzogranite (214 \pm $1 \mathrm{Ma}$ ) in the Laoniushan pluton (Qi et al., 2012) all have similar ages. These magmatic and mineralization ages coincide broadly with the Triassic NCC-YZC continental collision (Zhu et al., 2011), which occurred after the westward zipper-like closure of the Qinling Paleo-Tethyan Ocean in ca. 230-200 Ma (Zhu et al., 2011; Chen, 2010). Thus, we infer that the Late Triassic intra-continental Qinling orogeny has formed these voluminous magmatism and widespread Mo-U mineralization.

Subsequently, the Qinling Orogen underwent a tectonic 
transition due to the Paleo-Pacific subduction direction change (from NS- to EW-directed) at $145 \mathrm{Ma}$ (Lu, 1998; Zhao et al., 1994; Ren, 1991), accompanied by extensive magmatism well dated to be ca. 160-110 Ma (Yang et al., 2019; Wang et al., 2013). Coeval mineralization also occurred in the Xiaoqinling District, including the Shijiawan $(141 \pm 0.6 \mathrm{Ma}$; Zhao et al., 2013) and Jinduicheng (143.7 $\pm 3 \mathrm{Ma}$; Jiao et al., 2010) porphyry Mo deposits, and the overprinting mineralization in the Huayangchuan U-polymetallic deposit ( 129 Ma; Zheng et al., 2020a; Gao et al., 2019).

\subsection{Extra-Long Metallogenic History of the Huayang- chuan Ore Belt}

Ore deposits in the Huayangchuan ore belt yielded radiometric ages ranging from the Neoarchean to the Late Mesozoic, showing an extra-long metallogenic history. They have distinctive geological features or are hosted by different lithologies, and their formation was likely all related to the regional multistage tectono-magmatic evolution (Fig. 5).

The Archean Jialu quartz-carbonatite-type REE mineralization is closely related to the $\sim 2675$ Ma alkali magmatism, resulting from the NCC crustal growth. The REE mineralization may have resulted from the extensive fractionation of carbonatite magma and the metasomatism by late carbonatite magmatic-hydrothermal fluid, and the ore-forming material was mainly derived from the carbonatite magma, similar to the Bayan Obo and Maoniuping REE deposits (Fan et al., 2020). The Paleoproterozoic Caotan Fe deposit and the early-stage U mineralization at Huayangchuan may have had genetic link with the $\sim 2.3$ Ga plagioclase amphibolite and $\sim 1.8$ Ga pegmatite, respectively, which were likely generated by the NCC crustal reworking and the subsequent regional metamorphism. The Caotan Fe deposit is probably skarn-type, whose oreforming material was mainly sourced from intermediate-mafic magmas, whilst the Huayangchuan $U$ mineralization at this stage is probably pegmatite-type. The Paleozoic Yuejiawa quartz-sulfide vein-type $\mathrm{Cu}$ deposit $(418 \pm 23 \mathrm{Ma})$ has similar formation age to the Tongyu $(\mathrm{Cu}-\mathrm{Zn} ; 448 \pm 23$ and $390 \pm 19$ Ma) and Laochang (Pb-Zn-Cu; 440-406 Ma) VHMS deposits in the North Qinling belt, which may have also related to the north-dipping subduction of the Shangdan oceanic slab in the Early Paleozoic (Yan et al., 2017; Xiong et al., 2016). The similar tectonic background indicates that the ore-forming material at Yuejiawa may have derived from partial melting of the mantle wedge, similar to the Tongyu $\mathrm{Cu}$ deposit (Xiong et al., 2016). The Early Mesozoic Taoyuan quartz-sulfide vein-type Mo-U deposit has similar mineralization age to the Huayangchuan, Huanglongpu and Xigou deposits, which may have caused by the final closure of Qinling Paleo-Tethys Ocean. Their oreforming fluids were interpreted to be sourced from the deep source or upper mantle (Dai et al., 2018; Huang et al., 2009). However, the Late Mesozoic Jinduicheng and Shijiawan porphyry Mo deposits may have associated with subduction of the Paleo-Pacific oceanic plate, and the ore-forming material was mainly lower crust-derived (Zhao et al., 2013; Jiao et al., 2010).

\section{CONCLUSIONS}

(1) Pyrite and magnetite Re-Os dating yielded very differ- ent ages for the mineralization at the Jialu REE ( $\sim 275 \mathrm{Ma})$, Caotan Fe ( 2 $127 \mathrm{Ma})$, Yuejiawa $\mathrm{Cu}(\sim 418 \mathrm{Ma})$, and Taoyuan Mo-U ( $\sim 235 \mathrm{Ma})$ deposits in the Huayangchuan ore belt.

(2) Mineralization in the Huayangchuan ore belt displays an extra-long metallogenic history, and likely occurred in response to regional tectono-magmatic events.

\section{ACKNOWLEDGMENTS}

This study is financially supported by the Academician Workstation of Sino Shaanxi Nuclear Industry Group (Nos. ZSH-YS190101 and ZSH-YS180101) and Major Project of Basic and Applied Basic Research in Guangdong Province (No. 2019B030302013). We thank Bingshuang Zhao and Mengning Dai for their lab assistance, and the staffs of Geological Party No. 224 (Sino Shaanxi Nuclear Industry Group) for their field assistance. We are very grateful to the editor and three anonymous reviewers for their insightful comments that improved considerably the earlier version of the manuscript. The final publication is available at Springer via https://doi.org/10.1007/ s12583-021-1557-1.

Open Access: This article is licensed under a Creative Commons Attribution 4.0 International License, which permits use, sharing, adaptation, distribution and reproduction in any medium or format, as long as you give appropriate credit to the original author(s) and the source, provide a link to the Creative Commons licence, and indicate if changes were made. The images or other third party material in this article are included in the article's Creative Commons licence, unless indicated otherwise in a credit line to the material. If material is not included in the article's Creative Commons licence and your intended use is not permitted by statutory regulation or exceeds the permitted use, you will need to obtain permission directly from the copyright holder. To view a copy of this licence, visit http:// creativecommons.org/licenses/by/4.0/.

\section{REFERENCES CITED}

Bai, X. S., Liang, Z. C., Guo, P. F., et al., 2002. Geological Survey Report of Caotan Fe Deposit in Huayin City, Shaanxi Province No. 139 Brigade of Shaanxi Provincial Bureau of Coal Geology, Xi' an. Unpublished Report. 1-23 (in Chinese)

Bao, Z. W., Wang, C. Y., Zhao, T. P., et al., 2014. Petrogenesis of the Mesozoic Granites and Mo Mineralization of the Luanchuan Ore Field in the East Qinling Mo Mineralization Belt, Central China. Ore Geology Reviews, 57: 132-153. https://doi. org/10.1016/j. oregeorev. 2013.09.008

Bi, S. J., Li, J. W., Li, Z. K., 2011. Geological Significance and Geochronology of Paleoproterozoic Mafic Dykes of Xiaoqinling Gold District, Southern Margin of the North China Craton. Earth Science, 36 (1): 17-32 (in Chinese with English Abstract)

Birck, J. L., Barman, M. R., Capmas, F., 1997. Re-Os Isotopic Measurements at the Femtomole Level in Natural Samples. Geostandards and Geoanalytical Research, 21(1): 19-27. https://doi. org/10.1111/j.1751-908x.1997.tb00528.x

Cai, J. X., Yu, L. L., Xu, D. R., et al., 2020. Multiple Episodes of TectonoThermal Disturbances in the Huayangchuan U-Nb-Pb Polymetallic Deposit in the Xiaoqinling Region, Central China and Their Significances on Metallogeny. Ore Geology Reviews, 127: 103755. 
https://doi.org/10.1016/j.oregeorev.2020.103755

Cao, M. P., Yao, J. M., Deng, X. H., et al., 2017. Diverse and Multistage $\mathrm{Mo}, \mathrm{Au}, \mathrm{Ag}-\mathrm{Pb}-\mathrm{Zn}$ and $\mathrm{Cu}$ Deposits in the Xiong' er Terrane, East Qinling: From Triassic Cu Mineralization. Ore Geology Reviews, 81: 565-574. https://doi.org/10.1016/j.oregeorev.2016.02.014

Chen, Y. J., 2010. Indosinian Tectonic Setting, Magmatism and Metallogenesis in Qinling Orogen, Central China. Geology in China, 37(4): 854-865 (in Chinese with English Abstract)

Condie, K. C., Aster, R. C., 2010. Episodic Zircon Age Spectra of Orogenic Granitoids: The Supercontinent Connection and Continental Growth. Precambrian Research, 180(3/4): 227-236. https://doi. org/10.1016/j. precamres.2010.03.008

Condie, K. C., O'Neill, C., Aster, R. C., 2009. Evidence and Implications for a Widespread Magmatic Shutdown for $250 \mathrm{My}$ on Earth. Earth and Planetary Science Letters, 282(1/2/3/4): 294-298. https://doi.org/ 10.1016/j.eps1.2009.03.033

Deng, X. Q., Peng, T. P., Zhao, T. P., et al., 2019. Petrogenesis of the Late Paleoproterozoic ( 1.84 Ga) Yuantou A-Type Granite in the Southern Margin of the North China Craton and Its Tectonic Implications. Acta Petrologica Sinica, 35(8): 2455-2469 (in Chinese with English Abstract)

Dai, J. Z., Qian, Z. Z., Gao, J. S., et al., 2018. Geological and Geochemical Characteristics of the Xigou Mo Deposit in Huaxian County, Shaanxi Province: Constraint for Its Metallogenesis. Bulletin of Mineralogy, Petrology and Geochemistry, 37(4): 705-713. https://doi.org/10.19658/ j.issn.1007-2802.2018.37.048 (in Chinese with English Abstract)

Ding, L. X., Ma, C. Q., Li, J. W., et al., 2011. Timing and Genesis of the Adakitic and Shoshonitic Intrusions in the Laoniushan Complex, Southern Margin of the North China Craton: Implications for PostCollisional Magmatism Associated with the Qinling Orogen. Lithos, 126(3/4): 212-232. https://doi.org/10.1016/j.lithos.2011.07.008

Ding, L. X., Ma, C. Q., Li, J. W., et al., 2016. Geochronological, Geochemical and Mineralogical Constraints on the Petrogenesis of Appinites from the Laoniushan Complex, Eastern Qinling, Central China. Geochemistry, 76(4): 579-595. https://doi.org/10.1016/j.chemer. 2016.10.002

Diwu, C.R., Liu, X., Sun, Y., 2018. The Composition and Evolution of the Taihua Complex in the Southern North China Craton. Acta Petrologica Sinica, 34(4): 999-1018 (in Chinese with English Abstract)

Dong, Y. P., Zhang, G. W., Neubauer, F., et al., 2011. Tectonic Evolution of the Qinling Orogen, China: Review and Synthesis. Journal of Asian Earth Sciences, 41(3): 213-237. https://doi.org/10.1016/j.jseaes. 2011.03.002

Dong, Y. P., Santosh, M., 2016. Tectonic Architecture and Multiple Orogeny of the Qinling Orogenic Belt, Central China. Gondwana Research, 29(1): 1-40. https://doi.org/10.1016/j.gr.2015.06.009

Fan, H. R., Niu, H. C., Li, X. C., et al., 2020. The Types, Ore Genesis and Resource Perspective of Endogenic REE Deposits in China. Science Bulletin, 65: 3778-3793 (in Chinese)

Gao, L. G., Chen, Y. W., Bi, X. W., et al., 2019. Chronology and Mineral Chemistry of the Uranium Minerals in Huayangchuan UraniumNiobium Deposit, Shaanxi Province and Itsimplications for Uranium Mineralization. Acta Geologica Sinica, 93(9): 2273-2291. https://doi. org/10.19762/j.cnki.dizhixuebao.2019203 (in Chinese with English Abstract)

Guo, B., Zhu, L.M., Li, B., et al., 2009. Zircon U-Pb Age and Hf Isotope Composition of the Huashan and Heyu Granite Plutons at the Southern Margin of North China Craton: Implications for Geodynamic Setting.
Acta Petrologica Sinica, 25(2): 265-281 (in Chinese with English Abstract)

Guo, W., Zhou, D. W., Ren, J. F., et al., 2008. Characteristics of the Huayangchuan Ductile Shear Zones in the Xiaoqinling Mountains, Shaanxi, China, and Its Regional Tectonic Significance. Geological Bulletin of China, 27(6): 823-828. https://doi.org/10.3969/j.issn.16712552.2008.06.010 (in Chinese with English Abstract)

He, S., Li, Z. Y., Hui, X. C., et al., 2016. ${ }^{40} \mathrm{Ar}{ }^{39} \mathrm{Ar}$ Geochronology of Biotite in Huayangchuan Uranium-Polymetallic Deposit in Shaanxi Province and Its Geological Significance. Uranium Geology, 32: 161-166 (in Chinese with English Abstract)

Hu, J., Jiang, S. Y., Zhao, H. X., et al., 2012. Geochemistry and Petrogenesis of the Huashan Granites and Their Implications for the Mesozoic Tectonic Settings in the Xiaoqinling Gold Mineralization Belt, NW China. Journal of Asian Earth Sciences, 56: 276-289. https:// doi.org/10.1016/j.jseaes.2012.05.016

Huang, D. H., Nie, F. J., Wang, Y. C., et al., 1984. Lead Isotope Compositions of Molybdenum Deposits in East Qinling as Applied to the Problem of Ore Sources. Mineral Deposits, 3(4): 20-28 (in Chinese)

Huang, D. H., Wu, C. Y., Du, A. D., et al., 1995. Re-Os Isotope Ages of Molybdenum Deposits in East Qinling and Their Significance. Chinese Journal of Geochemistry, 14(4): 313-322

Huang, D. H., Hou, Z. Q., Yang, Z. M., et al., 2009. Geological and Geochemical Characteristics, Metallogenetic Mechanism and Tectonic Setting of Carbonatite Vein-Type $\mathrm{Mo}(\mathrm{Pb})$ Deposits in the East Qinling Molybdenum Ore Belt. Acta Geologica Sinica, 83(12): 1968-1984 (in Chinese with English Abstract)

Huang, J. C., Huang, Z. Y., Nan, B. J., 1972. Survey and Evaluation of Jialu Rare Earth Element Deposit in Luonan City, Shaanxi Province. No. 139 Brigade of Shaanxi Geological Bureau, Xi' an. Unpublished Report, 1-59 (in Chinese)

Huang, X. W., Qi, L., Wang, Y. C., et al., 2014. Re-Os Dating of Magnetite from the Shaquanzi $\mathrm{Fe}-\mathrm{Cu}$ Deposit, Eastern Tianshan, NW China. Science China Earth Sciences, 57(2): 267-277. https://doi.org/10.1007/ s11430-013-4660-z

Jia, X. L., 2016. Research for Taihua Complex in Xiaoqinling and Lushan Areas: Implications for the Evolution of the Crystalline Basement in Southern North China Craton: [Dissertation]. Northwest University, $\mathrm{Xi}$ ' an (in Chinese with English Abstract)

Jia, X. L., Zhai, M. G., Xiao, W. J., et al., 2020. Mesoarchean to Paleoproterozoic Crustal Evolution of the Taihua Complex in the Southern North China Craton. Precambrian Research, 337: 105451. https://doi.org/10.1016/j.precamres.2019.105451

Jiang, S. Y., Yang, J. H., Zhao, K. D., et al., 2000. Re-Os Isotope Tracer and Dating Methods in Ore Deposit Research. Journal of Nanjing University (Natural Sciences), 36: 669-677 (in Chinese with English Abstract)

Jiang, H. J., Gao, C., Kang, Q., et al., 2020. Mineralization Paragenesis of Huayangchuan U-Nb-Pb Deposit in the Lesser Qinling. Geotectonica et Metallogenia, 6: 404-421 (in Chinese with English Abstract)

Jiao, J. G., Tang, Z. L., Qian, Z. Z., et al., 2010. Metallogenic Mechanism, Magma Source and Zircon U-Pb Age of Jinduicheng Granitic Porphyry, East Qinling. Earth Science, 35: 1011-1012 (in Chinese with English Abstract)

Li, C. L., 2011. The Geochronology and Tectonic Implications of Granite Gneiss and Xiaohe Granite in Taihua Group of Xiaoqinling Area: [Dissertation]. China University of Geosciences, Beijing (in Chinese 
with English Abstract)

Li, J., Jiang, X. Y., Xu, J. F., et al., 2014. Determination of Platinum-Group Elements and Re-Os Isotopes Using ID-ICP-MS and N-TIMS from a Single Digestion after Two-Stage Column Separation. Geostandards and Geoanalytical Research, 38(1): 37-50. https://doi.org/10.1111/ j.1751-908x.2013.00242.x

Li, X. C., Yang, K. F., Spandler, C., et al., 2021. The Effect of Fluid-Aided Modification on the Sm-Nd and Th-Pb Geochronology of Monazite and Bastnäsite: Implication for Resolving Complex Isotopic Age Data in REE Ore Systems. Geochimica et Cosmochimica Acta, 300: 1-24. https://doi.org/10.1016/j.gca.2021.02.028

Liu, Y. C., 2002. Detailed Survey Report of Yuejiawa Cu Deposit Huayang Town, Huayin City, Shaanxi Province. Huayin Shunfa Copper Co. Ltd., Huayin. Unpublished Report. 1-27 (in Chinese)

Lu, X. X., 1998. The Evolutional Process of Qinling Tectonics Revealed by Qinling Granite-Advance in Study on Qinling Granite. Advance in Earth Science, 13: 213-214 (in Chinese with English Abstract)

Ludwig, K. R., 2003. User's Manual for Isoplot 3.6: A Geochronological Toolkit for Microsoft Excel. Berkeley Geochronology Center, Berkeley

Morgan, J. W., Walker, R. J., 1989. Isotopic Determinations of Rhenium and Osmium in Meteorites by Using Fusion, Distillation and IonExchange Separations. Analytica Chimica Acta, 222(1): 291-300. https://doi.org/10.1016/s0003-2670(00)81904-2

Peng, Y. S., Zhou, Q. S., Cai, W. H., et al., 1983. Analysis of Uranium Mineralization Characteristics and Metallogenic Geological Conditions in Taoyuan-Huanglongpu Area. No. 203 Research Institute of Nuclear Industr, Xianyang. Unpublished Report. 1-56 (in Chinese)

Qi, Q. J., Wang, X. X., Ke, C. H., et al., 2012. Geochronology and Origin of the Laoniushan Complex in the Southern Margin of North China Block and Their Implications: New Evidences from Zircon Dating, Hf Isotopes and Geochemistry. Acta Petrologica Sinica, 28: 279-301 (in Chinese with English Abstract)

Qiu, J. X., Yu, X. H., Zeng, G. C., et al., 1993. The Alkaline Rocks of Qinling-Bashan. Geology Publishing House, Beijing (in Chinese)

Ren, J. S., 1991. The Basic Characteristics of the Tectonic Evolution of the Continental Lithosphere in China. Regional Geology of China, 10(4): 289-293 (in Chinese)

Selby, D., Creaser, R. A., Stein, H. J., et al., 2007. Assessment of the ${ }^{187}$ Re Decay Constant by Cross Calibration of Re-Os Molybdenite and U-Pb Zircon Chronometers in Magmatic Ore Systems. Geochimica et Cosmochimica Acta, 71(8): 1999-2013. https://doi. org/10.1016/j. gca. 2007.01.008

Selby, D., Kelley, K. D., Hitzman, M. W., et al., 2009. Re-Os Sulfide (Bornite, Chalcopyrite, and Pyrite) Systematics of the CarbonateHosted Copper Deposits at Ruby Creek, Southern Brooks Range, Alaska. Economic Geology, 104(3): 437-444. https://doi. org/10.2113/ gsecongeo.104.3.437

Smoliar, M. I., Walker, R. J., Morgan, J. W., 1996. Re-Os Ages of Group IIA, IIIA, IVA, and IVB Iron Meteorites. Science, 271(5252): 10991102. https://doi.org/10.1126/science.271.5252.1099

Stein, H. J., Markey, R. J., Morgan, J. W., et al., 1997. Highly Precise and Accurate Re-Os Ages for Molybdenite from the East Qinling Molybdenum Belt, Shaanxi Province, China. Economic Geology, 92(7/ 8): 827-835. https://doi.org/10.2113/gsecongeo.92.7-8.827

Stein, H. J., Morgan, J. W., Scherstén, A., 2000. Re-Os Dating of LowLevel Highly Radiogenic (LLHR) Sulfides: The Harnas Gold Deposit, Southwest Sweden, Records Continental-Scale Tectonic Events. Economic Geology, 95(8): 1657-1671. https://doi.org/10.2113/
95.8.1657

Song, W., Xu, C., Smith, M. P., et al., 2016. Origin of Unusual HREE-MoRich Carbonatites in the Qinling Orogen, China. Sci Rep, 6: 37377. https://doi.org/10.1038/srep37377

Tan, J., Wei, J. H., Yang, C. F., et al., 2006. Application State of Isotopic Dating Methods for Ore Deposits. Geology and Prospecting, 42(3): 61-66 (in Chinese with English Abstract)

Wang, J. S., Wen, H. J., Li, C., et al., 2019. Age and Metal Source of Orogenic Gold Deposits in Southeast Guizhou Province, China: Constraints from Re-Os and He-Ar Isotopic Evidence. Geoscience Frontiers, 10(2): 581-593. https://doi.org/10.1016/j.gsf.2018.05.012

Wang, T. H., Mao, J. W., Xie, G. Q., et al., 2008. Sr, Nd, Pb Isotopic Composition of the Meso-Basic Dykes in the Xiaoqinling-Xiong' ershan Area, Henan Province, Central China and Its Tectonic Significance. Acta Geologica Sinica, 82(11): 1580-1591 (in Chinese)

Wang, X. X., Wang, T., Zhang, C. L., 2013. Neoproterozoic, Paleozoic, and Mesozoic Granitoid Magmatism in the Qinling Orogen, China: Constraints on Orogenic Process. Journal of Asian Earth Sciences, 72: 129-151. https://doi.org/10.1016/j.jseaes.2012.11.037

Walker, R. J., Morgan, J. W., Horan, M. F., et al., 1994. Re-Os Isotopic Evidence for an Enriched-Mantle Source for the Noril'sk-Type, OreBearing Intrusions, Siberia. Geochimica et Cosmochimica Acta, 58 (19): 4179-4197. https://doi.org/10.1016/0016-7037(94)90272-0

Xiong, X., Zhu, L. M., Yuan, H. L., et al., 2016. In-situ Microanalysis of Pb Isotopic Compositions Using FsLA-MC-ICP-MS for the Tongyu Copper Deposit in the North Qinling Orogen and Its Geological Significance. Chinese Science Bulletin, 61(25): 2811-2822 (in Chinese with English Abstract)

Xue, S., Xu, Y., Ling, M. X., et al., 2018. Geochemical Constraints on Genesis of Paleoproterozoic A-Type Granite in the South Margin of North China Craton. Lithos, 304/305/306/307: 489-500. https://doi. org/10.1016/j.lithos.2018.02.022

Xue, S., Ling, M. X., Liu, Y. L., et al., 2020. The Formation of the Giant Huayangchuan U-Nb Deposit Associated with Carbonatite in the Qingling Orogenic Belt. Ore Geology Reviews, 122: 103498. https:// doi.org/10.1016/j.oregeorev.2020.103498

Yan, Z., Chen, L., Buckman, S., et al., 2017. Stratigraphy and Tectonic Setting of Laochang Massive Sulfide Deposit in the North Qinling Belt, Central China. Ore Geology Reviews, 81: 96-111. https://doi.org/ 10.1016/j.oregeorev.2016.09.019

Yang, C. S., Zhao, L. D., Zheng, H., et al., 2019. The Multiple Granitic Magmatism in the Giant Huayangchuan Uranium Polymetallic Ore District: Implications for Tectonic Evolution of the Southern Margin of North China Craton in the Qinling Orogen. Ore Geology Reviews, 112: 103055. https://doi.org/10.1016/j.oregeorev.2019.103055

Yu, X. H., 1992. Geological, Mineralogical Characteristics and Origin of the Carbonatites from Huayangchuan, Shaanxi Province. Earth Science, 17: 151-158 (in Chinese with English Abstract)

Yuan, H. C., Wang, R. T., Jiao, J. G., et al., 2014. Re-Os Isotopic Ages of Molybdenites from Xigou Mo Deposit in Huaxian of East Qinling and Their Geological Significance. Journal of Earth Sciences and Environment, 36(1): 120-127 (in Chinese with English Abstract)

Zeng, W., Xu, Y. W., Sun, F. Y., et al., 2019. Molybdenite Re-Os Geochronology and $\mathrm{S}, \mathrm{Pb}$ Isotopic Characteristics of Banchang Copper Polymetallic Deposit in Neixiang, Henan Province. Earth Science, 44 (1): 109-122. https://doi.org/10.3799/dqkx.2018.294

Zhang, G. W., Zhang, Z. Q., Dong, Y. P., 1995. Nature of Main TectonoLithostratigraphic Units of the Qinling Orogen: Implications for the 
Tectonic Evolution. Acta Petrologica Sinica, 11(2): 101-114 (in Chinese with English Abstract)

Zhang, H. F., Gao, S., 2012. Geochemistry. Geological Publishing House, Beijing. 180-184 (in Chinese)

Zhang, X. K., Ye, H. S., Li, Z. Y., et al., 2015. Zircon U-Pb Ages, Hf Isotopic Composition and Geochemistry of Dafuyu Granitoid Poluton from Huashan Complex Batholith in Xiaoqinling. Mineral Deposits, 34(2): 235-260. https://doi. org/10.16111/j. 0258-7106.2015.02.003 (in Chinese with English Abstract)

Zhao, H. J., Mao, J. W., Ye, H. S., et al., 2010. Geochronology and Geochemistry of the Alkaline Granite Porphyry and Diabase Dikes in Huanglongpu Area of Shaanxi Province: Petrogenesis and Implications for Tectonic Environment. Geology in China, 37(1): 12-27 (in Chinese with English Abstract)

Zhao, H. J., Ye, H. S., Li, C., 2013. Re-Os Dating of Molybdenite from the Shijiawan Molybdenum Deposit in Shaanxi Province and Its Geological Implications. Acta Petrologica et Mineralogica, 32: 90-98 (in Chinese with English Abstract).

Zhao, Y., Yang, Z. Y., Ma, X. H., 1994. Geotectonic Transition from Paleoasian System and Paleotethyan System to Paleopacific Active
Continental Margin in Eastern Asia. Scientia Geologica Sinica, 29(2): 105-119 (in Chinese)

Zheng, H., Chen, H. Y., Li, D. F., et al., 2020a. Timing of CarbonatiteHosted U-Polymetallic Mineralization in the Supergiant Huayangchuan Deposit, Qinling Orogen: Constraints from Titanite U$\mathrm{Pb}$ and Molybdenite Re-Os Dating. Geoscience Frontiers, 11(5): 15811592. https://doi.org/10.1016/j.gsf.2020.03.001

Zheng, H., Chen, H. Y., Wu, C., et al., 2020b. Genesis of the Supergiant Huayangchuan Carbonatite-Hosted Uranium-Polymetallic Deposit in the Qinling Orogen, Central China. Gondwana Research, 86: 250-265. https://doi.org/10.1016/j.gr.2020.05.016

Zhu, L. M., Zhang, G. W., Guo, B., et al., 2008. U-Pb (LA-ICP-MS) Zircon Dating for the Large Jinduicheng Porphyry Mo Deposit in the East Qinling, China, and Its Metallogenetic Geodynamical Setting. Acta Geologica Sinica, 82(2): 204-220 (in Chinese with English Abstract)

Zhu, L. M., Zhang, G. W., Chen, Y. J., et al., 2011. Zircon U-Pb Ages and Geochemistry of the Wenquan Mo-Bearing Granitioids in West Qinling, China: Constraints on the Geodynamic Setting for the Newly Discovered Wenquan Mo Deposit. Ore Geology Reviews, 39(1/2): 4662. https://doi.org/10.1016/j.oregeorev.2010.10.001 